\title{
PENGARUH MEDIA PEMBELAJARAN ROLE PLAYING BERBANTUAN MEDIA PEMBELAJARAN KOMIK DIGITAL TERHADAP HASIL BELAJAR KOGNITIF PADA MATA PELAJARAN IPA TERPADU KELAS VIII SMP NEGERI MANDALA RAIMANUK
}

\author{
Viktoria Isa', Melkias A. Manggoa ${ }^{1}$, Agus Maramba Meha ${ }^{1 *}$ \\ ${ }^{1}$ Program Studi Pendidikan Biologi, Fakultas Keguruan dan IImu Pendidikan, Universitas \\ Kristen Artha Wacana, Kupang-NTT
}

*Corresponding author: us.meha17@gmail.com

\begin{abstract}
ABSTRAK
Salah satu kendala utama dalam proses belajar khususnya Pelajaran IPA Terpadu adalah kurangnya konsentrasi dan motivasi siswa dalam pembelajaran IPA Biologi, sehingga menyebabkan rendahnya hasil belajar siswa. penelitian bertujuan untuk mengetahui pengaruh model pembelajaran role playing berbantuan media pembelajaran komik digital terhadap hasil belajar siswa. Metode yang digunakan adalah quasi eksperimen, dengan desain penelitian posttest only control design. Teknik pengumpulan data menggunakan Tes Hasil Belajar. Data hasil belajar dianalisis menggunakan Rumus uji-t berbantuan uji statistik SPSS versi 16. Hasil penelitian menunjukkan adanya pengaruh yang signifikan penggunaan model pembelajaran role playing berbantuan media pembelajaran komik digital terhadap hasil belajar siswa, dibuktikan dengan thitung lebih besar dari tabel yaitu 6,488>1,674.
\end{abstract}

Kata Kunci: Model Pembelajaran Role Playing, Media Pembelajaran Komik Digital, Hasil Belajar Kognitif

\begin{abstract}
One of the main obstacles in the learning process, especially Integrated Science Lessons, is the lack of concentration and motivation of students in learning Science Biology, which causes low student learning outcomes. The research aims to see the effect of role playing learning model assisted by digital comic learning media on student learning outcomes. The method used is a quasi-experimental, with a posttest research design only control design. The data technique uses the Learning Outcomes Test. The learning outcomes data were analyzed using the t-test formula assisted by the SPSS version 16 statistical test. The results showed a significant effect of the use of the role playing learning model assisted by digital comic learning media on student learning outcomes, as evidenced by the tcount greater than t table, namely $6.488>1.674$.
\end{abstract}

Keywords: Role Playing Learning Model, Digital Comic Learning Media, Cognitive Learning Outcomes 
Pelaksanaan pembelajaran yang efktitif dan efisien memerlukan penerapan model pembelajaran dan media pembelajaran yang bervariasi dari seorang guru, sebagai salah satu factor yang menentukan keberhasilan siswa, selain faktor dari dalam diri siswa itu sendiri. Oleh karena itu penggunaan model pembelajaran dan media pembelajaran yang baik hendaknya disesuaikan dengan karakteristik materi pokok yang akan disampaikan.

Salah satu model pembelajaran dan media pembelajaran yang membantu tercapainya hasil belajar siswa adalah model pembelajaran role playing berbantuan media pembelajaran komik digital, dikarena dapat membuat siswa aktif dan tertarik dengan pembelajaran. Komalasari (2011:80) role playing adalah suatu model penguasaan bahan-bahan pembelajaran melalui pengembangan imajinasi dan penghayatan siswa. Pengembangaan imajinasi dan penghayatan dilakukan siswa dengan memerankannya sebagai tokoh hidup atau benda mati. Permainan ini pada umumnya dilakukan oleh lebih dari satu orang, hal ini tergantung kepada apa yang diperankan.

Selanjutnya Barokah (2012) menjelaskan komik digital adalah komik yang berbentuk format digital berbasis elektronik yang tidak hanya menampilkan alur cerita saja, namun didalamnya dapat disisipkan game, animasi, film, atau aplikasi lainnya yang mempermudah pembaca dalam mengikuti dan menikmati tiap cerita dan penyimpannya dapat dilakukan secara online ataupun melalui gadget tertentu.

Penggunaan model dan media yang bervariasi dalam pembelajaran dapat menciptakan hasil belajar siswa yang baik. Hasil belajar sebagai terjadinya perubahan tingkah laku pada diri seseorang yang dapat diamati dan diukur bentuk pengetahuan, sikap dan keterampilan. Perubahan tersebut dapat diartikan sebagai terjadinya peningkatan dan pengembangan yang lebih baik dari sebelumnya dan yang tidak tahu menjadi tahu, (Hamalik, 2007). Selanjutnya Arsyad (2005) menjelaskan hasil belajar merupakan perubahan tingkah laku pada diri seseorang yang mungkin disebabkan oleh terjadinya perubahan pada tingkat pengetahuan, keterampilan, atau sikapnya. Perubahan diarahkan pada diri peserta didik secara terencana, baik dalam aspek pengetahuan, keterampilan, maupun sikap.

Berdasarkan observasi awal pada SMP Negeri Mandala Raimanuk, diketahui bahwa penggunaan media dalam proses pembelajaran IPA Terpadu di sekolah masih terbatas pada pengunaan gambar yang dibuat dengan kertas karton dan power point. Karena tidak semua kelas memiliki LCD dan proyektor sehingga penggunaan media dengan power point pun jarang digunakan oleh guru. Diketahui juga bahwa terdapat beberapa kendala dalam pelaksanaan proses pembelajaran.

Salah satu kendala utama dalam proses belajar khususnya Pelajaran IPA Terpadu, adalah konsentrasi siswa kurang terfokus pada pembelajaran IPA Biologi dan kurangnya motivasi siswa dalam pembelajaran IPA Terpadu. Selama proses pembelajaran berlangsung siswa tidak berani untuk menanyakan materi yang belum dipahami, siswa kurang aktif dalam proses pembelajaran, hal tersebut tampak ketika guru memberi kesempatan siswa untuk bertanya maupun berpendapat tidak dimanfaatkan dengan baik oleh siswa. Permasalahan tersebut mengakibatkan rendahnya aktifitas belajar dan rendahnya hasil belajar siswa.

Pada proses pembelajaran di SMP Negeri Mandala Raimanuk, khususnya untuk mata pelajaran IPA Terpadu hasil data diperoleh bahwa siswa kelas VIII yang diharapkan mencapai Kriteria Ketuntasan Minimal (KKM) yang ditetapkan disekolah yakni seorang siswa dikatakan telah tuntas belajar jika hasil belajar siswa telah mencapai skor 75 dan suatu kelas dikatakan tuntas terhadap suatu materi pelajaran jika skor rata-rata kelas $75 \%$. Sesuai data yang diperoleh dari guru mata pelajaran IPA Terpadu SMP Negeri Mandala Raimanuk terlihat bahwa hasil belajar siswa berupa nilai ulangan harian IPA Terpadu kelas VIII B hanya 10 orang yang tuntas yaitu $35,71 \%$ dan 18 orang yang tidak tuntas yaitu $64,28 \%$. Nilai tertinggi yang dicapai adalah 80 sedangkan nilai terendah 35. Nilai rata-rata yang diperoleh yaitu 46 sementara Kriteria Ketuntasan Minimal (KKM) yang ditetapkan sekolah adalah 75. Pada kelas VIII C hasil data yang diperoleh seluruh siswa nilai ulangan harian mereka tidak mencapai Kriteria Ketuntasan (KKM) yaitu nilai tertinggi mereka 65. Penelitian ini bertujuan untuk mengetahui pengaruh model pembelajaran role playing berbantuan media pembelajaran komik digital terhadap hasil kognitif belajar IPA Terpadu Kelas VIII pada materi sistem pencernaan makanan di SMP Negeri Mandala Raimanuk tahun ajaran 2018/2019". 


\section{METODE PENELITIAN}

\section{Metode Penelitian}

Metode yang digunakan dalam penelitian ini adalah metode eksperimen semu (quasi eksperimen). Sugiyono, (2012) Metode eksperimen adalah adalah metode penelitian yang digunakan untuk mencari pengaruh perlakuan tertentu terhadap yang lain dalam kondisi yang terkendalikan.

\section{Populasi Dan Sampel}

\section{Populasi}

populasi adalah wilayah generalisasi yang terdiri atas: objek atau subjek yang mempunyai kualitas dan kerakteristik tertentu yang ditetapkan oleh peneliti untuk dipelajari dan kemudian ditarik kesimpulan (Sugiyono, 2011:80). Yang menjadi populasi dalam penelitian ini

\section{Sampel}

Sampel adalah jumlah dan bagian dari karakteristik yang dimiliki oleh populasi tersebut (Sugiyono 2012:118). Sampel yang diambil dalam penelitian ini adalah siswa kelas VIII C yang berjumlah 26 orang sebagai kelas eksperimen dan VIII 28 yang berjumlah orang sebagai kelas kontol. Pengambilan sampel dilakukan dengan teknik purposive sampling yaitu pemilihan sampel berdasarkan pertimbangan trendahnya hasil belajar.

\section{Desain Penelitian}

Desain penelitian ini menggunakan Quasi Eksperimental, dalam bentuk Posttest Only Control Grousp Design. Dalam desain ini terdapat dua kelompok yang masing-masing dipilih secara random (R). Kelompok pertama diberikan perlakuan $(\mathrm{X})$ dan kelompok lain tidak. Kelompok yang diberi perlakuan disebut kelompok eksperimen dan kelompok yang tidak diberikan perlakuan disebut kelompok kontrol.

\begin{tabular}{|lll|}
\hline $\mathbf{R}$ & $\mathbf{X}$ & $\mathbf{O}_{2}$ \\
$\mathbf{R}$ & & $\mathbf{O}_{4}$ \\
\hline
\end{tabular}

\section{Keterangan:}

$\mathrm{R}=$ Kelompok dipilih secara Random

$\mathrm{X}=$ Perlakuan atau sesuatu yang diujikan

$\mathrm{O}_{2}=$ Hasil Posttest Kelas Eksperimen

$\mathrm{O}_{4}=$ Hasil Posttest Kelas Kontrol

\section{Prosedur Penelitian}

1. Tahap Persiapan

Pada tahap persiapan, peneliti harus menyiapkan instrument penelitian, yang menjadi instrumen dalam penelitian ini adalah menyiapkan rencana pelaksanaan pembelajaran (RPP), silabus, bahan ajar dan soal tes. Pada tahap persiapan ini yang menjadi kelas kontrol adalah kelas VIII B dan yang menjadi kelas eksperimen adalah kelas VIII C.

2. Tahap Pelaksanaan

Pada tahap ini peneliti :

a. Kelas eksperimen

Pada kelas eksperimen peneliti menyampaikan materi pembelajaran kepada siswa selama 2-3 kali pertemuan dengan menggunakan model pembelajaran role playing berbantuan model pembelajaran komik digital. Sesudah menyampaikan materi pembelajaran peneliti memberikan tes untuk mengukur hasil belajar siswa. Setelah mendapat pembelajaran dengan menggunakan model pembelajaran role playing berbantuan model pembelajaran komik digital maka dilakukan tes akhir. Pemberian tes 
akhir bertujuan untuk mengetahui penguasaan siswa terhadap materi Sistem Pencernaan Makanan.

b. Kelas control

Pada kelas kontrol peneliti menyampaikan materi dengan menerapkan metode pembelajaran konvensional lalu membagikan siswa lembar kerja untuk dijawab.

\section{Teknik Pengumpulan Data}

Teknik pengumpulan data ini menggunakan Tes Hasil Belajar.

\section{Teknik Analisis Data}

Pengelolaan data dalam penelitian ini dilakukan dengan menggunakan Rumus uji t Polled Varians dengan alat uji statistik SPSS versi 16 sebagai berikut:

Keterangan:

$$
t=\frac{\bar{X}_{1}-\bar{X}_{2}}{\sqrt{\frac{\left(n_{1}-1\right) s_{1}^{2}+\left(n_{2}-1\right) s_{2}^{2}}{n_{1}+n_{2}-2}\left(\frac{1}{n_{1}}-\frac{1}{n_{2}}\right)}}
$$

$X_{1}=$ rata-rata sampel satu

$X_{2}=$ rata-rata sampel dua

$S_{1}^{2}=$ varian sampel satu

$S_{2}^{2}=$ varian sampel dua

$n_{1}=$ jumlah sampel satu

$n_{2}=$ jumlah sampel dua

\section{HASIL DAN PEMBAHASAN}

\section{Pemaparan Hasil Penelitian}

\section{Deskripsi Data Hasil Belajar Kelas Eksperimen}

Sesuai dengan tujuan penelitian adalah untuk mengetahui pengaruh model pembelajaran role playing berbantuan model pembelajaran komik digital terhadap hasil belajar siswa pada pokok bahasan sistem pencernaan pada manusia. Untuk mengetahui hasil belajar siswa, maka peneliti menggunakan tes dan memberikan skor untuk mengetahui hasil belajar siswa setelah pembelajaran berlangsung.

\section{Penyajian Kata Kelas Eksperimen}

Sesuai penelitian pada kelas eksperimen hasil belajar yang diperoleh setelah menggunakan media pembelajaran komik digital berbantuan model pembelajaran role playing dari 26 siswa, hasil belajar semua siswa mencapai tingkat tetuntasan yaitu dengan presentasi ketuntasan untuk kelas eksperimen yaitu 86,15 . Siswa memiliki hasil belajar sangat tinggi dengan menerapkanmodel pembelajaran role playing berbantuan model pembelajaran komik digital.

Berdasarkan data yang diperoleh melalui hasil olahan lembar aktivitas belajar siswa pada kelas eksperimen diperoleh skor tertinggi 100dan skor terendah 70 nilai yang paling sering muncul (modus) adalah 80-84yaitu sebanyak 11 siswa. Nilai rata-rata pada kelas eksperimen (mean) 80 dan median terletak pada interval 90-94 dengan nilai 90. Jumlah perolehan skor nilai keseluruhan siswa adalah 2.240 dengan nilai rata-rata 80. Nilai distribusi frekuensi kelas eksperimen dapat digambarkan pada grafik. 


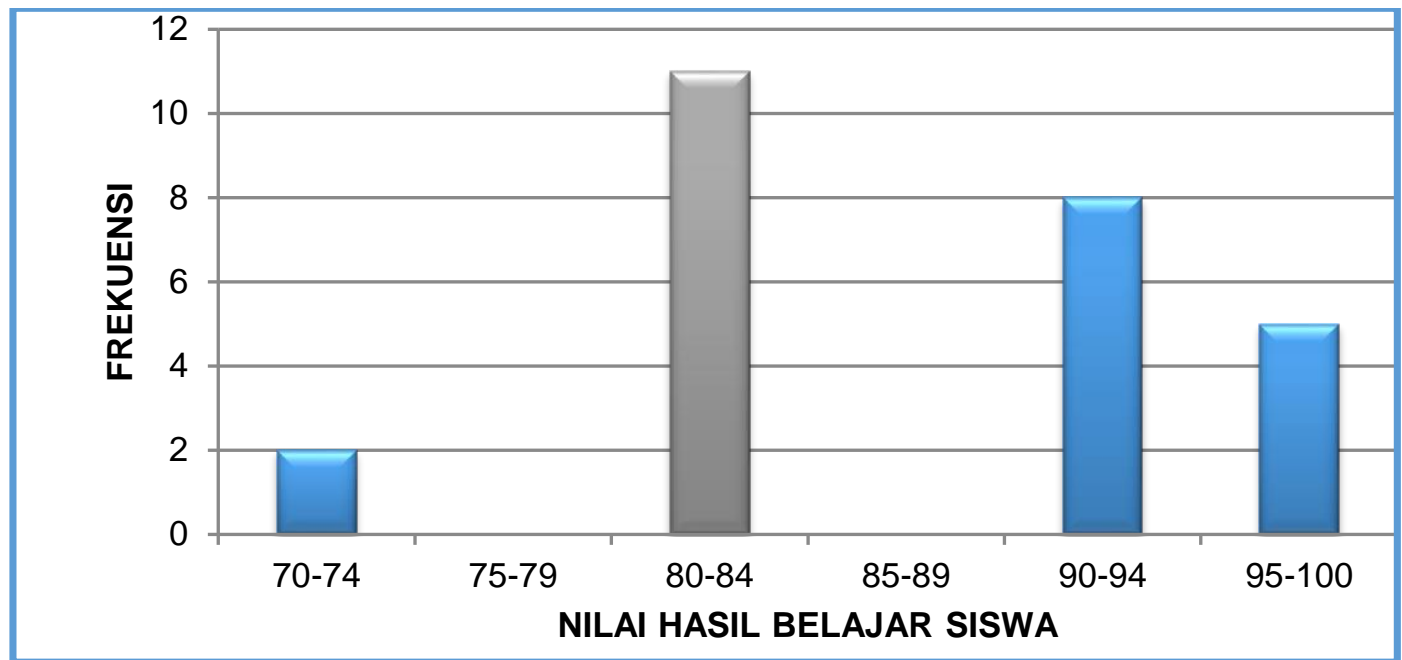

Gambar 1. Nilai distribusi frekuensi kelas eksperimen

Nilai distribusi frekuensi kelas eksperimen dapat digambarkan pada grafik. Selama kegiatan pembelajaran siswa menunjukan aktivitas-aktivitas belajar dalam strategi komik digital dimana siswa mampu untuk mendengar, memperhatikan, mengamati, menanya, melakukan percobaan, menalar dan mengkomunikasikan apa yang didapatkan selama kegiatan pembelajaran, dalam strategi pembelajaran ini dapat membangkitkan motivasi belajar siswa sehinga membuat siswa lebih aktif dalam kegiatan belajar.

\section{Penyajian Data Kelas Kontrol}

Sesuai dengan penelitian pada kelas kontrol dari 28 siswa hasil belajar siswa tidak ada yang mencapai tingkat ketuntasan nilai rata-rata yang mereka peroleh yaitu 61,78 . Siswa belum memiliki aktivitas belajar pada kelas kontrol dengan menggunakan model pembelajaran konvensional.

Berdasarkan data yang diperoleh melalui hasil olahan lembar aktivitas belajar siswa pada kelas kontrol diperoleh skor. tertinggi kelas kontrol diperoleh nilai tertinggi 80 dan nilai terendah 40, nilai yang paling sering muncul (modus) adalah 68-74 yaitu sebanyak 10 siswa. Nilai rata-rata pada kelas kontrol (mean) 70 dan median terletak pada interval 54-60. Jumlah perolehan skor nilai keseluruhan siswa adalah 1.730 dengan nilai rata-rata 70 . Nilai distribusi frekuensi kelas kontrol dapat digambarkan pada grafik.

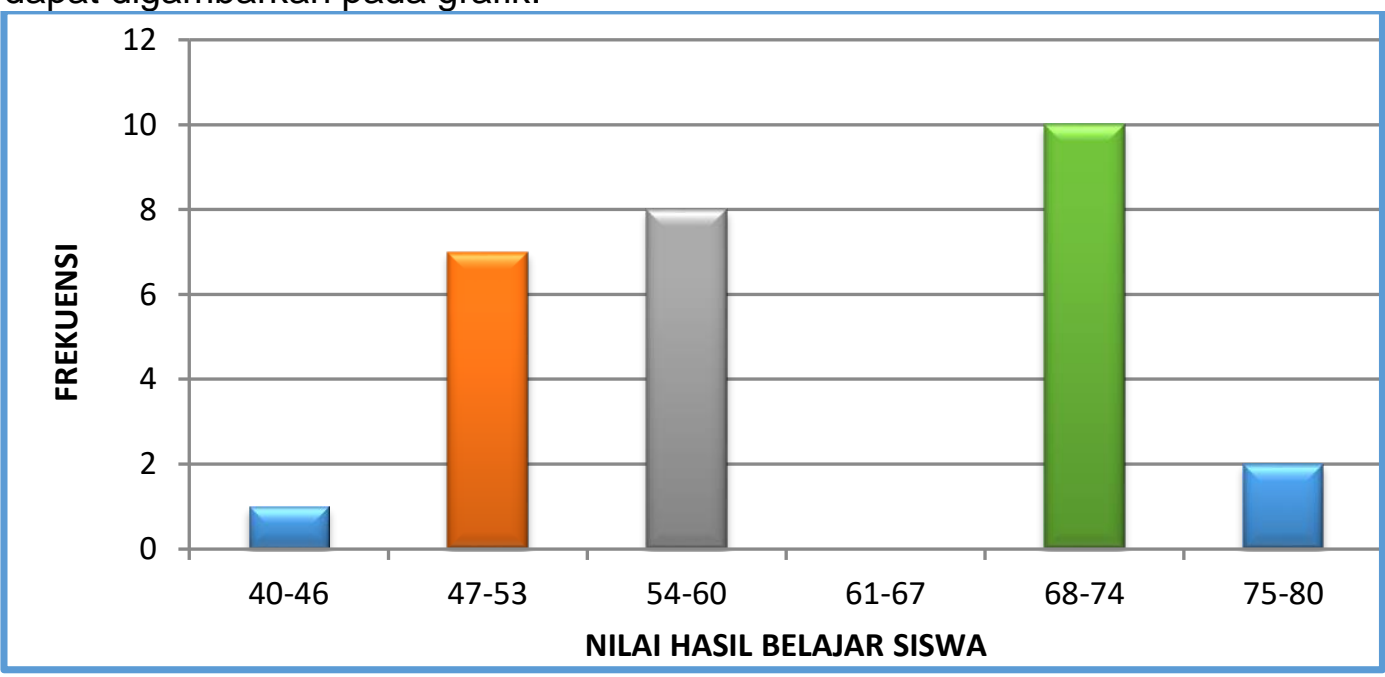

Gambar 2. Nilai distribusi frekuensi kelas kontrol 
Nilai distribusi frekuensi kelas kontrol dapat digambarkan pada grafik. Selama kegiatan pembelajaran siswa menunjukan hasil belajar dalam media komik digital. Pada kegiatan pembelajaran dikelas kontrol, sebagian siswa kurang aktif selama kegiatan pembelajaran. Hal ini disebabkan kurangnya kegiatan-kegiatan belajar siswa seperti melakukan percobaan dalam kegiatan belajar, siswa tidak dituntut untuk menalar akan kegiatan belajar yang berlangsung dan pada akhir kegiatan belajar tidak adanya kesimpulan akhir dalam kegiatan belajar. perbedaan kelas kontrol dengan kelas eksperimen disebabkan karena pada kelas kontrol aktivitas pembelajarannya kurang melibatkan siswa sehinga membuat siswa kurang aktif dalam kegiatan pembelajaran.

\section{Analisis Data Dan Penguji Hipotesis}

\section{Uji prasyarat dan analisis}

Sebelum dilakukan pengujian hipotesis terlebih dahulu dilakukan uji prasyarat, yaitu uji homogenitas dan normalitas. Apabila hasil yang diperoleh dari pengujian tersebut menunjukan bahwa data yang diperoleh telah terdistribusi normal maka uji hipotesis dapat dilakukan menggunakan uji t.

\section{Uji homogenitas}

Pengujian homogenitas ini untuk mengetahui apakah data penelitian kelas eksperimen dan kelas kontrol mempunyai varians sama atau tidak. Uji homogenitas data penelitian ini menggunakan data postes dan untuk menentukan sampel penelitian dilakukan dengan bantuan SPSS 16,0. Data dikatakan homogen jika taraf signifikan lebih besar dari $0,05(p>0,05)$ nilai tersebut menunjukan bahwa varian antara data tidak berbeda atau homogen. Sedangkan jika taraf signifikan kurang dari $0,05(\mathrm{p}<0,05)$ maka distribusi dikatakan tidak homogen. Hasil uji homogenitas data penelitian ini dapat dilihat pada Tabel.

Tabel 1 Uji Homogenitas

\begin{tabular}{rrrr}
\hline $\begin{array}{l}\text { Levene } \\
\text { Statistic }\end{array}$ & df1 & df2 & Sig. \\
\hline, 520 & 1 & 52 & 0.474 \\
\hline
\end{tabular}

Berdasarkan Tabel 1 diketahui bahwa nilai signifikan adalah 0,474 atau lebih besar dari 0,05. Hal tersebut menunjukan bahwa data penelitian homogen.

\section{Uji Normalitas Hasil Belajar Siswa}

Uji normalitas merupakan uji yang dilakukan untuk mengetahui normal tidaknya distribusi dari data yang telah dikumpulkan. Suatu distribusi dikatakan normal jika taraf signifikana lebih besar dari 0,05. Namun jika taraf signifikan kurang dari 0,05 maka distribusi dikatakan tidak normal. Hasil uji normalitas penelitian data posttes ini menunjukan bahwa data yang di kumpulkan terdistribusi secara normal. Data hasil uji normalitas dapat dilihat pada Tabel.

Tabel 2. Uji normalitas Hasil Belajar Siswa

\begin{tabular}{llr}
\hline \multirow{2}{N}{} & & Nilai \\
\hline Normal & Mean & 54 \\
\cline { 2 - 3 } Parameters & Std. Deviation & 81,92 \\
\hline Most Extreme & Absolute & 12,967 \\
Differences & Positive & .210 \\
\cline { 2 - 3 } & Negative & .210 \\
\hline Kolmogorov-Smirnov Z & -.174 \\
\hline Asymp. Sig. (2-tailed) & 2.543 \\
\hline Test distribution is Normal. & .102 \\
\hline
\end{tabular}


Berdasarkan data yang diperoleh dari hasil uji One-Sample Kolmogorov-Smirnov Test dapat dikatakan bahwa data tersebut berdistribusi normal karena memiliki signifikan $>1,02$.

\section{Uji Hipotesis}

a. pengujian hipotesis dilakukan untuk mengetahui ada tidaknya pengaruh Hasil perhitungan uji normalitas dan homogenitas, menunjukan bahwa aktivitas belajar siswa berdistribusi normal, dan homogen. Sehingga uji hipotesis dapat digunakan dalam penelitian ini menggunakan uji statistik yaitu uji $t$. Uji ini digunakan untuk mengambil keputusan apakah hipotesis diterima atau ditolak. Dalam analisis tersebut, kriteria yang digunakan untuk meneriam hipotesis nihil $\left(\mathrm{H}_{0}\right)$ dan hipotesis alternatif $\left(\mathrm{H}_{1}\right)$ yaitu : (1). Jika angka signifikan > 0,05 maka $\mathrm{H} 1$ diterima dan $\mathrm{H} 0$ ditolak, dan (2). Jika angka signifikan < 0,05 maka $\mathrm{H} 0$ diterima dan $\mathrm{H} 1$ ditolak. Hasil uji t terdapat data motivasi belajar siswa dapat dilihat pada Tabel 3

\begin{tabular}{|c|c|c|c|c|c|c|c|c|c|}
\hline \multicolumn{10}{|c|}{ Tabel 3. Independent Samples Test } \\
\hline & \multicolumn{3}{|c|}{$\begin{array}{l}\text { Levene's } \\
\text { Test for } \\
\text { Equality of } \\
\text { Variances }\end{array}$} & \multicolumn{6}{|c|}{ t-test for Equality of Means } \\
\hline & & & & & $\begin{array}{l}\text { Sig. } \\
(2- \\
\text { tailed }\end{array}$ & $\begin{array}{c}\text { Mean } \\
\text { Differen }\end{array}$ & $\begin{array}{l}\text { Std. } \\
\text { Error } \\
\text { Differe }\end{array}$ & $\begin{array}{r}95 \% \text { Cor } \\
\text { Interval } \\
\text { Differ }\end{array}$ & $\begin{array}{l}\text { fidence } \\
\text { of the } \\
\text { ence }\end{array}$ \\
\hline & $\mathrm{F}$ & Sig. & $\mathrm{T}$ & df & ) & ce & nce & Lower & Upper \\
\hline $\begin{array}{ll}\text { Nila } & \text { Equal } \\
\mathrm{i} & \text { variances } \\
& \text { assumed }\end{array}$ &, 520 & ,474 & 6,488 & 52 & .000 & 21,923 & 3,379 & 15,143 & 28,703 \\
\hline $\begin{array}{l}\text { Equal } \\
\text { variances not } \\
\text { assumed }\end{array}$ & & & 6,466 & 50,639 & .000 & 21,923 & 3,390 & 15,116 & 28,731 \\
\hline
\end{tabular}

Berdasarkan hasil perhitungan uji perbedaan rata-rata yang disajikan pada tabel 3. Diketahui pada kolom Levene's Test for Equality of Variances memiliki nilai signifikan sebesar $4,74(p>0,05)$. Data tersebut menunjukkan bahwa kedua varians adalah sama, maka penggunaan varians untuk membandingkan nilai rata-rata dalam pengujian $t$ test harus dengan dasar Equal variances assumed. Pada Equal variances assumed diperoleh nilai t sebesar 6,488 dan taraf signifikan $p=0,000$ atau kurang dari 0,05 . Hal tersebut menunjukkan bahwa terdapat perbedaan hasil belajar siswa pada kelas kontrol yang hanya menggunakan model pembelajaran ceramah dan diskusi dan kelas eksperimen yang menggunakan model pembelajaran role playing berbantuan media pembelajaran komik digital.

Hasil uji t yang diperoleh menunjukkan bahwa ada pengaruh dari model role playing karena nilai t yang diperoleh adalah 6,488 terdapat perbedaan aktivitas belajar siswa pada kelas kontrol dan kelas eksperimen. Dimana pada kelas kontrol sistem pembelajarannya adalah ceramah dan diskusi sedangkan pada kelas eksperimen proses pembelajarannya menggunakan model pembelaljaran role playing berbantuan media pembelajaran komik digital. Siswa pada kelas eksperimen memiliki aktivitas belajar yang lebih tinggi 60,56\% dibandingkan aktivitas belajar siswa pada kelas kontrol. Fakta tersebut menunjukan bahwa penerapan model pembelajaran role playing berbantuan media pembelajaran komik digital memiliki potensi yang besar pada hasil belajar siswa.

\section{PEMBAHASAN}

Hasil uji t yang diperoleh menunjukkan bahwa ada pengaruh dari model pembelajaran role playing berbantuan media pembelajaran komik digital karena nilai t yang diperoleh adalah 6,488 terdapat perbedaan aktivitas belajar siswa pada kelas kontrol dan kelas eksperimen. Dimana pada 
kelas kontrol sistem pembelajarannya adalah ceramah dan diskusi sedangkan pada kelas eksperimen proses pembelajarannya menggunakan model pembelajaran role playing berbantuan media pembelajaran komik digital. Siswa pada kelas eksperimen memiliki aktivitas belajar yang lebih tinggi 60,56\% dibandingkan aktivitas belajar siswa pada kelas kontrol. Fakta tersebut menunjukan bahwa penerapan model pembelajaran role playing berbantuan media pembelajaran komik digital memiliki potensi yang besar pada hasil belajar siswa. Hasil penelitian yang dilakukan Nurhasanah (2016) menunjukkan bahwa Penerapan metode role playing mengantarkan siswa kedalam pembelajaran yang menyenangkan, melibatkan siswa menjadi aktif serta berdampak pada peningkatan hasil belajar siswa.

Berdasarkan hasil posttest kelas eksperimen, skor terendah (minimum) yang diperoleh siswa adalah 70 dan skor tertinggi (maksimum) sebesar 100. Dari 26 siswa yang tuntas 24 sedangkan yang tidak tuntas 2 siswa. Jumlah nilai posttest dari 26 siswa sebesar 2.240. Sehingga diperoleh nilai rata-rata untuk posttest sebesar 86,15 . Jadi nilai rata-rata siswa setelah memberikan perlakuan menggunakan model pembelajaran role playing berbantuan media pembelajaran komik digital adalah 86,15. Sedangkan kelas kontrol menggunakan pembelajaran konvensional ini, dapat membuat siswa jenuh sehingga sangatlah berpengaruh pada hasil belajar siswa. Dalam hal ini, pada kelas kontrol siswa berjumlah 28 orang skor terendah (minimum) 40 dan skor tertinggi (maksimum) sebesar 80. Dari 28 siswa yang tuntas 2 siswa yang tidak tuntas 26 siswa. Jumlah nilai posttest dari 28 siswa sebesar 1.730. Jumlah nilai rata-rata posttest sebesar 61,78 . Hasil penelitian Kasanah (2019) menunjukkan siswa yang mengikuti pembelajaran menggunakan model pembelajaran Role Playing berbantu media Multiply Cards menjadi lebih semangat untuk mengikuti proses pembelajaran karena diselingi dengan permainan. sehingga siswa yang mengikuti pembelajaran menggunakan model pembelajaran Role Playing berbantu media Multiply Cards memiliki hasil belajar yang lebih tinggi dibandingkan dengan saat menggunakan model pembelajaran konvensional.

Berdasarkan hasil perhitungan dengan menggunakan rumus uji t menunjukkan bahwa ada pengaruh yang signifikan hal ini dapat dilihat pada nilai $t_{\text {hitung }}$ yakni 6,488 lebih besar dari $t$ tabel dengan taraf signifikan 5\% yakni 1,674 maka, berdasarkan uji hipotesis $\mathrm{H}_{1}$ terima dan $\mathrm{H}_{0}$ di tolak. Artinya penggunaan model pembelajaran role playing berbantuan media pembelajaran komik digital berpengaruh secara signifikan terhadap hasil belajar IPA terpadu siswa kelas VIII SMP Negeri Mandala Raimanuk Tahun ajaran 2018/2019.

Kendala yang dihadapi pada saat penelitian yaitu pada pertemuan I pemberian perlakuan tidak berjalan secara maksimal. Hal ini terjadi karena peneliti masih dalam proses penyesuaian dengan siswa dan baru pertama kali menggunakan model pembelajaran role playing berbantuan media pembelajaran komik digital dalam proses pembelajaran. Keterlaksanaan komik digital oleh siswa juga kurang optimal, hal ini karena siswa belum terbiasa dengan model pembelajaran role playing berbantuan media pembelajaran komik digital. Kurangnya pengelolaan kelas dan pengelolaan waktu oleh peneliti juga masih salah satu faktor penyebab ketidak terlaksanaannya tahapan-tahapan media pembelajaran komik digital secara menyeluruh, sehingga hal tersebut menjadi catatan bagi peneliti untuk pembelajaran berikutnya.

Selanjutnya proses pembelajaran pada pertemuan II pemberian perlakuan berjalan dengan baik, tahapan model pembelajaran role playing berbantuan media pembelajaran komik digital telah dilaksanakan seluruhnya baik oleh guru maupun siswa. Walaupun masih ada beberapa kendala, karena siswa harus beradaptasi dengan perubahan pembelajaran yakni berorientasi kepada siswa. Peran peneliti sebagai fasilitator, sedangkan siswa dituntut untuk belajar mandiri. Dalam pelaksanaan pembelajaran guru perlu untuk mencipatkan pembelajaran yang melibatkan keaktifan seluruh siswa. Pelenitian yang dilakukan Sani (2020) mengemukakan bahwa Guru perlu berusaha maksimal untuk membimbing siswa, menciptakan suasana yang memotivasi siswa untuk mengembangkan diri, termasuk memberikan bahan diskusi dan melibatkan semua siswa dalam kegiatan belajar, agar dapat meningkatkan hasil belajar siswa.

Setelah menerapkan model pembelajaran role playing berbantuan media pembelajaran komik digital peneliti melihat adanya hasil belajar yang sangat baik saat menggunakan model pembelajaran role playing berbantuan media pembelajaran komik digital, karena siswa diberikan 
Indigenous Biologi

Jurnal pendidikan dan Sains Biologi

3(2) 2020

kesempatan untuk mempraktek materi didepan kelas yang berkaitan dengan dengan materi, ternyata siswa lebih tertarik dengan hal tersebut karena siswa tidak hanya mendengarkan materi yang diajarkan, tetapi dapat mengamati peristiwa yang terjadi.

\section{KESIMPULAN}

Berdasarkan hasil penelitian dan pembahasan yang telah dilakukan maka dapat disimpulkan bahwa model pembelajaran role playing berbantuan media pembelajaran komik digital berpengaruh secara signifikan terhadap hasil belajar siswa. Hal ini dapat dilihat nilai $t_{\text {hitung }}$ yakni 6,488 lebih besar dari t tabel dengan taraf signifikan $5 \%$ yakni 1,674 .

\section{SARAN}

Adapun saran dari hasil penelitian ini adalah: agar guru dapat menerapkan model pembelajaran role playing berbantuan media pembelajaran komik digital ini, sehingga dapat menciptakan suasana kelas yang aktif serta dapat mengoptimalkan hasil belajar siswa.

\section{DAFTAR PUSTAKA}

Arsyad, A. (2005). Media Pembelajaran. Jakarta: PT RajaGrafindo Persada

Barokah, S. 2012. Pengembangan Komik Digital Berbasis Nilai Karakter Sebagai Media Pembelajaran Akuntansi Pada Kompetensi Dasar Menyusun Laporan Keuangan Perusahaan Jasa Untuk SMA XI.

Hamalik, O. 2007. Proses Belajar Mengajar. Jakarta: Bumi Aksara, 2007

Kasanah, S. A., Damayani, A. T., \& Rofian, R. (2019). Keefektifan Model Pembelajaran Role Playing Berbantu Media Multiply Cards terhadap Hasil Belajar Siswa. Jurnal IImiah Sekolah Dasar, 3(4), 519-526.

Komalasari, K. 2011 . Pembelajaran Kontekstual Konsep dan Aplikasi.Bandung: PT Refika Aditama.

Nurhasanah, I. A., Sujana, A., \& Sudin, A. (2016). Penerapan Metode Role Playing Untuk Meningkatkan Hasil Belajar Siswa Pada Materi Hubungan Mahluk Hidup Dengan Lingkungannya. Jurnal Pena IImiah, 1(1), 611-620.

Sani, M. M. R., Meha, A. M., \& Nenotek, S. A. (2020). Penerapan Model Siklus Belajar 5E Untuk Meningkatkan Kemampuan Berpikir Tingkat Tinggi (HOTS) Siswa di SMP Adhyaksa 2 Kupang Tahun Ajaran 2018/2019. Jurnal Sains dan Edukasi Sains, 3(1), 15-23.

Slameto, 2003. Belajar dan Faktor-Faktor Yang Mempengaruhinya, Jakarta: Rineka Cipta.

Sugiyono. 2008. Metode Penelitian Pendidikan Pendekatan Kuantitatif, Kualitatif, dan R\&D, Bandung: Alfabeta 